\title{
EFEK REFORMASI BIROKRASI TERHADAP KEMAJUAN EKONOMI DAERAH
}

\section{THE EFFECT OF BUREAUCRATIC REFORM TOWARD REGIONAL ECONOMICPROGRESS}

\author{
Rustan A. dan Mayahayati Kusumaningrum \\ PKP2A III Lembaga Administrasi Negara \\ Jl. H.M Ardans (Ring Road III) Samarinda-Kalimantan Timur \\ Email : rustanamarullah8@gmail.com; may_kaltim@yahoo.com
}

Naskah diterima: 3 Mei 2016, revisi pertama: 18 Agustus 2016.

\begin{abstract}
Local economic activity tends to be influenced by the capabilities of the bureaucracy. If the bureau cracyisable to implement good governance principles and it has high concern on public service to create citizen welfare, so that the trend of local economic activity tends to grow highly. Furthermore, if the bureaucracy can successively encourage local economic activity, the local development and public welfare may relatively increase. Therefore, the efforts to reform the local bureaucracy will drive local development through trickle-down effect. This study uses descriptivequantitative approach with linear regression analysis on cross-section data from 99 local governments in 2014 which are considered as pilot projects. The result is that the bureaucratic reform contributes apositive and statistically significant impact on local economy. Two of three components of the bureaucratic reform that are assessed, namely Accountability Performance of Local Government (AKIP) and Public Services, bring statistically-significant and positive impact to the localrevenue (PAD), and each point of PAD's rise tends to createa statisticallysignificant and positive affect on local economic growth by $1.1 \%$.
\end{abstract}

Keywords: Bureaucratic Reform, Local Revenue, Regional Economic Growth

\begin{abstract}
Abstrak
Aktivitas ekonomi daerah cenderung dipengaruhi oleh kapabilitas birokrasi yang ada. Jika birokrasi menerapkan tata kelola pemerintahan yang baik dan pelayanan publiknya berorientasi pada kesejahteraan publik, maka kecenderungannya aktivitas ekonomi didaerah tersebut akan berkembang sangat tinggi. Jika birokrasi kemudian dapat mendorong aktivitas ekonomi daerah melaju, maka pembangunan dan kesejahteraan publik relatif akan meningkat. Oleh karenanya, upaya reformasi birokrasi diyakini akan membawa dampak turunan (trickle down effect) bagi kemajuan daerah. Penelitian ini secara deskriptif-kuantitatif menerapkan regresi linear pada data cross-section tahun 2014 pada 99 pemerintah daerah yang
\end{abstract}


ditetapkan sebagai pilot project reformasi birokrasi. Hasil analisis menunjukkan bahwa reformasi birokrasi relatif berperan positif dan signifikan terhadap progres ekonomi daerah. Dari ketiga komponen reformasi birokrasi yang dinilai, dua diantaranya (variabel AKIP dan pelayanan publik) memberikan dampak secara statistik positif dan signifikan terhadap pertambahan nilai PAD, dan setiap peningkatan PAD tersebut secara statistik positifsignifikan mempengaruhi pertumbuhan ekonomi daerah sebesar 1,1\%.

Kata Kunci: Reformasi Birokrasi, Pendapatan Asli Daerah, Pertumbuhan Ekonomi Daerah

\section{A. PENDAHULUAN}

Aktivitas ekonomi dan birokrasi dapat diibaratkan sebagai dua mata rantai yang saling terhubung dan tidak dapat dipisahkan. Birokrasi dapat memberikan jalan mulus ataupun jalan terjal bagi kelangsungan ekonomi suatu daerah, atau geliat ekonomi suatu daerah maju, stagnan, ataupun menurun akan merefleksikan kondisi birokrasi daerah tersebut. Oleh karenanya, perbaikan birokrasi oleh pemerintah daerah menjadi hal mutlak untuk dilakukan agar iklim investasi/ ekonomi daerah dapat tumbuh pesat. Namun demikian, beberapa daerah relatif belum menyadari bahwa birokrasi yang lebih akuntabel, bersahabat, dan memudahkan bagi investor akan menjadi daya tarik tersendiri. Hal ini diungkapkan Komite Pemantauan Pelaksanaan Otonomi Daerah (KPPOD) yang menjelaskan bahwa isu pokok yang selalu menjadi tantangan berusaha di Indonesia adalah tata kelola izin yang tidak efisien dan rawan malpraktik (korupsi) (KPPOD, 2012). Padahal, sebanyak 85 persen proses perizinan investasi dilakukan di daerah (Media Praja, 2015).

Jelas bahwa perilaku lembaga pemerintah atau birokrasi sangat berpengaruh terhadap aktivitas dunia usaha, khususnya dalam hal efektivitas dan efisiensi. Menurut WEF, birokrasi yang birokratis, red tape alias lambat dan berbelit-belit, over-regulasi, korup, tidak jujur, tidak transparan, tidak dapat dipercaya, dan dipolitisasi, akan mendongkrak biaya ekonomi yang harus dipikul para pengusaha secara signifikan sehingga dalam jangka panjang akan memperlambat laju pertumbuhan ekonomi (Gunarjo, 2011:54). Hal senada juga disebutkan oleh Kristiadi (1995) bahwa birokrasi yang diharapkan mampu menjadi enzim of growth perekonomian, dalam praktik justru sering membebani sektor ini. Tidak mengherankan jika pelaku ekonomi cenderung menganggap keberadaan birokrasi lebih banyak menghambat, alih-alih membantu percepatan perputaran roda perekonomian.

Berangkat dari fenomena tersebut, perubahan image dan citra pemerintah perlu dilakukan melalui pembenahan dan penguatan birokrasi. Sebab fakta menunjukkan pada masa-masa krisis ekonomi peningkatan peran lembaga pemerintah di bidang perekonomian terbukti mampu menghindarkan banyak negara dari kemungkinan krisis yang lebih berat(Gunarjo, 2011:54). Lembaga pemerintah yang kuat mampu menjaga daya saing dan pertumbuhan, di mana hal itu sangat mempengaruhi kepercayaan investasi, produktivitas (Gunarjo, 2011:54). Pembenahan birokrasi inilah yang kemudian melahirkan reformasi birokrasi yang saat ini gencar dilaksanakan pemerintah dan pemerintah daerah.

Dalam grand desain reformasi birokrasi (RB) telah ditetapkan target terukur keberhasilan pelaksanaan reformasi birokrasi hingga tahun 2014 yang dapat dijelaskan dalam tabel berikut: 
Tabel 1.

Sasaran dan Indikator Keberhasilan Reformasi Birokrasi 2010-2014

\begin{tabular}{|c|c|c|c|c|c|c|c|c|c|}
\hline Sasaran & \multicolumn{2}{|c|}{ Indikator } & $\begin{array}{l}\text { Baseline } \\
(2009)\end{array}$ & 2010 & 2011 & 2012 & 2013 & 2014 & $\begin{array}{l}\text { Target } \\
(2014)\end{array}$ \\
\hline \multirow{2}{*}{$\begin{array}{l}\text { Terwujudnya } \\
\text { pemerintahan yang } \\
\text { bersih dan bebas } \\
\text { KKN }\end{array}$} & \multicolumn{2}{|l|}{ IPK* } & 2.8 & 2.8 & 3.0 & 32 & 32 & 34 & 50 \\
\hline & $\begin{array}{l}\text { Opini } \\
\text { BPK } \\
\text { (WTP) }\end{array}$ & Daerah & $2.73 \%$ & $3 \%$ & $7 \%$ & $16 \%$ & $27 \%$ & $35 \%$ & $60 \%$ \\
\hline \multirow{2}{*}{$\begin{array}{l}\text { Terwujudnya } \\
\text { peningkatan } \\
\text { kualitas pelayanan } \\
\text { publik kepada } \\
\text { masyarakat }\end{array}$} & $\begin{array}{l}\text { Integritas } \\
\text { pelayanan } \\
\text { publik }\end{array}$ & Pusat & 6.64 & 6.2 & 7.1 & 6.86 & 7.37 & 7.22 & 8.0 \\
\hline & \multicolumn{2}{|c|}{$\begin{array}{l}\text { Peringkat } \\
\text { kemudahan berusaha }\end{array}$} & 122 & 121 & 129 & 128 & 120 & 114 & 75 \\
\hline $\begin{array}{l}\text { Meningkatnya } \\
\text { kapasitas dan } \\
\text { akuntabilitas } \\
\text { kinerja birokrasi }\end{array}$ & \multicolumn{2}{|c|}{$\begin{array}{l}\text { Indeks efektivitas } \\
\text { pemerintahan*** }\end{array}$} & -0.29 & -0.20 & -0.25 & -0.29 & n.a & n. $a$ & 0.5 \\
\hline
\end{tabular}

Sumber: Permenpan-RB No. 7 Tahun 2015

* Mulai Tahun 2012 skor indeks persepsi korupsi berubah dari skala 1-10 menjadi 1-100

Berdasarkan tabel 1 diatas terlihat bahwa sebagian besar target pencapaian reformasi birokrasi belum tercapai (khususnya pada level pemerintah daerah),dan merupakan tugas besar bagi pemerintah untuk mendorong agar pemerintah daerah segera mempercepat pelaksanaan reformasi birokrasi di daerahnya.Belum tercapainya target RB juga dapat diasumsikan bahwa kesadaran sebagian pemerintah daerah akan RB masih rendah dan cenderung belum memahami manfaat RB bagi pembangunan daerah, pertumbuhan ekonomi, dan termasuk pendapatan daerah.Nugroho (2013:55) dalam buku pemimpin dan reformasi birokrasi menerangkan bahwa sejumlah penelitian tentang kinerja reformasi birokrasi di Indonesia sepanjang 1998-2012 secara mendasar dan umum memberikan arah simpulan yang sebangun yaitu, sebagian besar proses reformasi birokrasi belum berhasil, sebagian kecil berhasil, dan sisanya tidak berjalan sama sekali.

Beberapa faktor terutama yang menghambat RB salah satunya adalah weak accountability dan bureaucratic dysfunction (Turner, 2013), Otonomi daerah juga relatif belum mampu melahirkan tingkat akuntabilitas dan transparansi, serta efektivitas dan efisiensi yang tinggi (Kristiansen and Santoso, 2006) sehingga berdampak (masih) pada terjadinya korupsi pada beberapa daerah.Pada aspek pelayanan publik, kondisi pelayanan publik tetap saja dipersepsikan buruk oleh publik, seperti pelayanan yang lama dan berbelit-belit, petugas yang kurang ramah, proses perizinan yang tidak jelas dan tanpa standar yang pasti. Reformasi birokrasi yang sudah digalakkan selama 11 tahun, tapi kondisi ini masih mewarnai pelayanan publik di indonesia(Haniah, et al., 2015:41). 


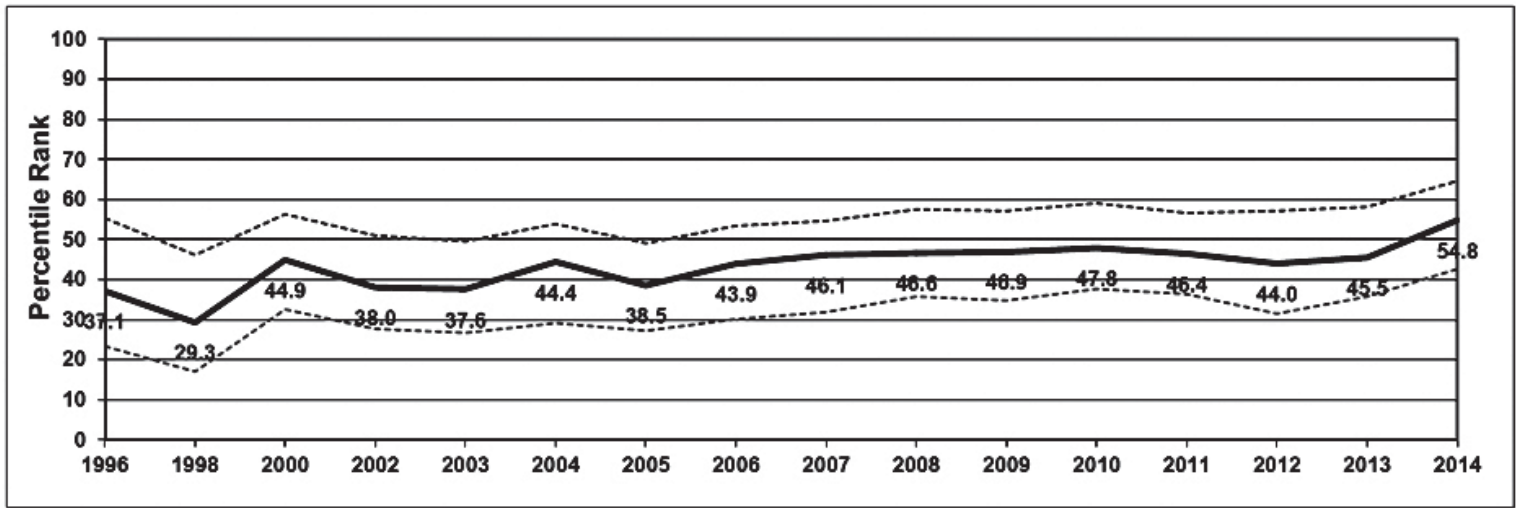

Sumber:World Bank, 2015:4.

Gambar 1.

Government Effectiveness di Indonesia Tahun 1996-2014

Perkembangan efektivitas pemerintahan ditunjukkan oleh Worldwide Governance Indicators (WGI) yang diterbitkan oleh the World Bank pada gambar 1 di atas. Efektifitas pemerintahan menangkap persepsi publik terhadap kualitas pelayanan publik, kualitas aparatur dan tingkat independensi birokrasi dari tekanan politik, kualitas formulasi kebijakan dan implementasinya, serta kredibilitas dan komitmen pemerintah terhadap kebijakan tersebut.Hasil tersebut menunjukkan efektivitas pemerintahan yang dinilai masih rendah dengan tingkat perbaikan yang cukup lambat.

Untuk mempercepat pelaksanaan reformasi birokrasi pada pemerintah daerah, telah ditetapkan 99 daerah sebagai pilot project reformasi birokrasi melalui Kepmenpan-RB No. 96 Tahun 2013 Tentang Penetapan Pilot Project Reformasi Birokrasi pada Pemerintah Daerah. Melalui penetapan ini diharapkan akan mendorong kualitas tata kelola pemerintahan yang bersih, efektif dan terpercaya sehingga dapat berdampak baik pada kemajuan daerah dan nasional. Namun demikian, hingga kini daerah-daerah yang ditetapkan sebagai pilot project RB tersebut belum pernah dievaluasi, hal ini diungkapkan dalam penjelasan laporan pada Permenpan-RB No. 7 Tahun 2015 Tentang Rencana Strategis Kemenpan-RB 2015-2019, bahwa untuk pemerintah daerah, seluruh provinsi dan 93 Kabupaten/Kota telah melakukan reformasi birokrasi. Namun belum dilakukan evaluasi, sehingga perkembangan reformasi birokrasinya belum diketahui. Meskipun belum dilakukan evaluasi, pelaksanaan RB di pemerintah daerah menunjukkan kemajuan yang signifikan. Hal ini ditunjukkan antara lain dengan kualitas pelayanan publik yang semakin membaik, pelaksanaan penerimaan CPNS yang semakin transparan, pelaksanaan promosi jabatan secara terbuka yang dilakukan di berbagai daerah serta trend nilai akuntabilitas kinerja yang meningkat (Penjelasan PermenpanRB No. 7 Tahun 2015).

Berdasarkan penjelasan tersebut, terdapat celah untuk melakukan evaluasi terhadap pelaksanaan RB di lingkungan pemerintah daerah. RB yang berhasil ditentukan pada kualitas pelayanan publik dan tata kelola pemerintahannya yang semakin membaik, dan hal ini akan mendorong aktivitas ekonomi daerah. Oleh karena itu, penelitian ini akan mengevaluasi pengaruh Reformasi Birokrasi khususnya pada aspek pengaruhnya terhadap ekonomi daerah. Untuk mendorong pembangunan ekonomi suatu daerah sangat bergantung pada investasi. Semakin tinggi pergerakan investasi di daerah tersebut maka pertumbuhan ekonomi daerah tersebut juga semakin tinggi. Kondisi ini menjadi latar belakang pemerintah daerah mendorong upaya penciptaan iklim 
investasi yang kondusif dan memudahkan. Hal ini dilakukan salah satunya melalui perbaikan tata kelola birokrasi atau reformasi birokrasi, sebab cara kerja lembaga pemerintah akan memberikan kontribusi positif terhadap kegiatan dunia usaha (Zuhro, 2007).

Adapun penelitian-penelitian sebelumnya yang mengangkat tema birokrasi dan progres ekonomi diantaranya penelitian Evans (1992) dalam Rauch (1995:968) yang berargumentasi bahwa

"Professionalization of the state bureaucracy is a necessary (though not sufficient) condition for a state to be developmental"

Rauch (1995) dalam penelitiannya memperoleh positive impact dari reform terhadap city growth melalui mekanisme peningkatan alokasi penganggaran pemerintah pada upayaupaya investasi jangka panjang. Penelitian lanjutan Evans dan Rauch (1999) yang mempergunakan cross-national data menyebutkan bahwa birokrasi weberian (yaitu birokrasi yang menerapkan mekanisme meritokrasi dan penghargaan) secara signifikan meningkatkan pertumbuhan ekonomi.Atau dengan kata lain, "quality of government" to be powerfully connected to economic growth, sehingga policy maker perlu memberikan perhatian bagi pembentukan birokrasi yang lebih baik (Evans dan Rauch, 1999:749).

Namun demikian, hasil berbeda ditemukan dalam penelitian Libman (2009:46) yang menunjukkan bahwa "increasing share of bureaucracy is harmful for economic growth". Hal ini disebabkan karena pemerintah cenderung untuk overinvest dalam penyediaan barang publik (public goods) sehingga menurunkan tingkat pertumbuhan ekonomi. Hasil serupa dalam penelitian cross sectional analysis pada 35 developing countries yang dilakukan oleh Lovett (2011:25), menyebutkan bahwa

"The effects of bureaucratic quality on GDP per capita have declined over time, an indication that bureaucratic institutions are becoming less important in the process of capital formation”.

Marfiana dan Kurniasih (2013) melakukan penelitian terhadap pemerintah daerah kabupaten/kota di pulau Jawa yang menguji pengaruh ukuran pemerintah daerah, tingkat kekayaan daerah, tingkat ketergantungan pada pemerintah pusat, belanja daerah, ukuran legislatif, hasil pemeriksaan audit BPK (temuan audit dan opini audit) terhadap kinerja keuangan pemerintah daerah. Hasil penelitian ini diantaranya menyebutkan bahwa opini audit tidak berpengaruh signifikan terhadap kinerja keuangan daerah.

Dari beberapa penelitian tersebut, terdapat dua kesimpulan yang saling bertolak belakang antara pengaruh birokrasi terhadap geliat perkembangan ekonomi daerah (memiliki hubungan secara positif dan ataukah negatif). Dengan demikian, penelitian ini juga sekaligus akan membuktikan apakah reformasi birokrasi mampu mendorong kemajuan ekonomi daerah atau justru sebaliknya.

\section{Rumusan Masalah dan Tujuan Penelitian}

Reformasi birokrasi yang sudah berlangsung sekitar 15 tahun telah diwarnai dengan berbagai upaya dan terobosan pemerintah dalam membenahi pelayanan publik maupun tata kelola birokrasinya. Langkah dan upaya tersebut membuat kepercayaan publik dan sektor privat mulai meningkat seiringpencapaian ekonomi dan pembangunan daerah yang optimal. Oleh karenanya, pertumbuhan ekonomi menjadi penting sebagai tolok ukur keberhasilan pemerintah daerah. Berangkat dari argumentasi tersebut, rumusan masalah pada penelitian 
ini adalah apakah reformasi birokrasi memberikan dampak positif dan signifikan bagi kemajuan ekonomi daerah?

Tujuan penelitian ini adalah melakukan penilaian secara umum pengaruh pelaksanaan reformasi birokrasi yang sudah dicanangkan terhadap progres ekonomi daerah. Selain itu, juga untuk memberikan dorongan kepada pemerintah daerah bahwa dengan fokus memperbaiki kinerja birokrasi akan berdampak signifikan terhadap kemajuan ekonomi daerah (termasuk iklim investasi), dibandingkan jika lebih berorientasi pada upaya menarik investor tanpa pembenahan birokrasi daerah.

\section{B. METODE PENELITIAN}

Penelitian ini membatasi ruang lingkupnya pada asumsi bahwa reformasi birokrasi yang berhasil ditandai dengan pencapaian hasil penilaian yang terbaik dari pemerintah. Komponen penilaian tersebut harus mencerminkan 3 sasaran reformasi birokrasi yaitu (Permenpan-RB No. 7 Tahun 2015):

1. Terwujudnya pemerintahan yang bersih dan bebas KKN Untuk menjawab pencapaian sasaran pertama ini, penelitian ini menggunakan laporan Opini BPK terhadap pengelolaan keuangan pemerintah daerah sebagai acuan analisis

2. Terwujudnya peningkatan kualitas pelayanan publik kepada masyarakat Untuk merefleksikan sasaran kedua ini, peneliti mempergunakan laporan penilaian kepatuhan pelayanan publik pemerintah daerah.

3. Meningkatnya kapasitas dan akuntabilitas kinerja birokrasi

Terkait sasaran ketiga, penelitian ini menggunakan laporan penilaian akuntabilitas kinerja instansi pemerintah daerah yang relatif dapat menggambarkan pencapaian reformasi birokrasi pada aspek akuntabilitas.

Ketiga komponen reformasi birokrasi tersebut selanjutnya akan dianalisis keterkaitannya dengan kemajuan ekonomi daerah.

Penelitian ini merupakan penelitian deskriptif dengan pendekatan kuantitatif. Analisis kuantitatif dilakukan dengan menggunakan metode regresi linear pada data cross-section di 99 pemerintah daerah Tahun 2014,dengan memanfaatkan prinsip Ordinary Least Square (OLS) dan menerapkan konsepsi dummy variabelpada formulasi statistik yang disusun. Adapun formulasi statistik yang digunakan adalah:

$$
\begin{aligned}
& P A D=C+\alpha_{2} B P K=\varepsilon \\
& P A D=C:+\alpha_{3} A K I P:+\varepsilon \text { : } \\
& P A D=C=+\alpha_{4} O R I=+\varepsilon \text { : } \\
& P D R B=C_{I}+\alpha_{1} P A D+\varepsilon
\end{aligned}
$$

Pemisahan formulasi statistik tersebut di atas dilakukan untuk menghindari pengaruh auto-correlation antar variabel, sehingga diharapkan dapat menghasilkan perhitungan yang lebih valid. Kerangka/ desain penelitian ini mengacu pada rumusan bahwa upaya reformasi birokrasi yang dilakukan oleh pemerintah daerah secara langsung akan memberikan impact kepada peningkatan PAD pemerintah daerah, dan keberhasilan reformasi birokrasi dalam mempengaruhi peningkatan PAD tersebut juga pada akhirnya akan berimbas pada pertumbuhan ekonomi daerah (Winarno, 2008:45). 


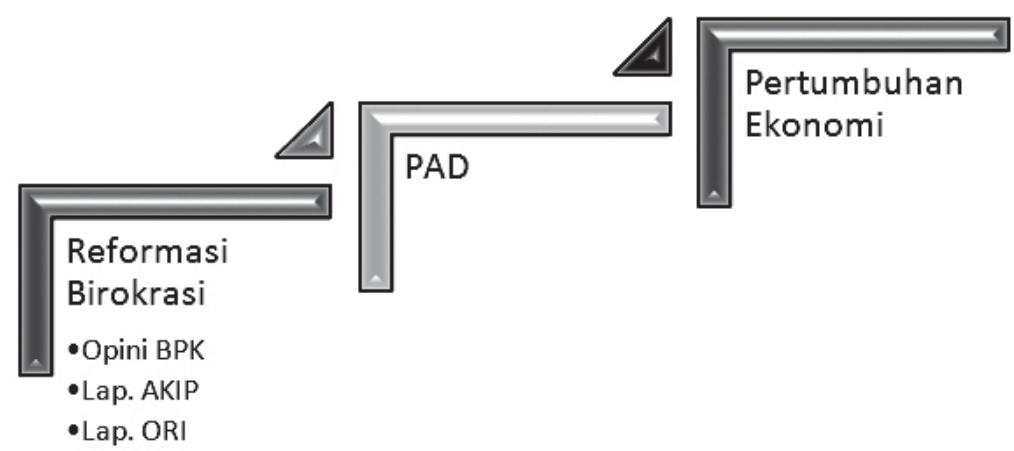

Gambar 2.

Kerangka/ Desain Penelitian

Pada formulasi statistik diatas, variabel PAD merefleksikan usaha mandiri pemerintah daerah dalam meningkatkan porsi APBD dan PDRB mereka, variabel BPK menunjukkan pengaruh opini pengelolaan keuangan pemerintah daerah terhadap peningkatan PAD, variabel AKIP menunjukkan pengaruh akuntabilitas kinerja pemerintah daerah terhadap peningkatan PAD, variabel ORI menunjukkan pengaruh tingkat kepatuhan pelayanan publik pemerintah daerah terhadap peningkatan PAD, sedangkan variabel PDRB menunjukkan aggregat pertumbuhan ekonomi daerah.Variabel BPK, AKIP, dan ORI dianalisis terhadap PAD dengan argumentasi bahwa ketiga komponen tersebut menunjukkan upaya reformasi birokrasi pemerintah daerah dan relatif keberhasilannya akan berhubungan erat dengan penerimaan daerah. Keseluruhan variabel ini (BPK, AKIP, dan ORI) diharapkan memberikan hasil yang positif terhadap peningkatan pendapatan asli daerah (PAD), sebab hal ini akan memperbesar kemampuan pemerintah daerah dalam membangun daerahnya secara mandiri, serta memperluas ruang gerak pembiayaan bagi berbagai program dan kegiatan peningkatan kesejahteraan publik yang kemudian secara langsung berdampak positif pada pertumbuhan ekonomi daerah (PDRB).

Adapun sampel yang digunakan dalam kajian ini adalah 99 pemerintah daerah (provinsi, kabupaten, dan kota) yang telah ditetapkan sebagai pilot project reformasi birokrasi sesuai dengan Kepmenpan-RB No. 96 Tahun 2013 Tentang Penetapan Pilot Project Reformasi Birokrasi pada Pemerintah Daerah.Ke-99 pemerintah daerah tersebut terdiri atas 34 Provinsi (termasuk Provinsi Kalimantan Utara), 32 Kota, dan 33 Kabupaten.

Data sekunder yang dikumpulkan dan digunakan terdapat dalam laporan-laporan yang di-publish tahun 2015 dengan data terakhir tahun 2014. Data-data tersebut yaitu, capaian PDRB dan PAD pemerintah daerah Tahun 2014, Laporan Akuntabilitasi Kinerja Instansi Pemerintah (AKIP) Tahun 2014yang dikeluarkan oleh Kementerian PAN-RB, Hasil Survey Kepatuhan Pelayanan Publik Tahun 2014 yang dikeluarkan oleh Lembaga Ombudsman Republik Indonesia (ORI), dan Opini Terhadap Laporan Keuangan Pemerintah Daerah Tahun 2014 yang dikeluarkan oleh Badan Pemeriksa Keuangan (BPK). Adapun data dan informasi pendukung lainnya bersumber dari buku, jurnal, hasil penelitian, proceeding, serta sumbersumber lainnya yang menunjang penelitian ini.

\section{KERANGKA TEORI}

\section{Reformasi Birokrasi : Apa dan Mengapa}

Quah dalam Mustafa (2013:136) mendefinisikan reformasi sebagai suatu proses untuk mengubah proses dan prosedur birokrasi publik dan sikap serta tingkah laku birokrat untuk mencapai 
efektivitas birokrasi dan tujuan pembangunan nasional. Reformasi birokrasi adalah penataan ulang secara bertahap dan sistematis dengan correct dan perfect atas fungsi utama pemerintah demi kelancaran pendayagunaan aparatur negara yang kualitasnya semakin meningkat dan kenyal, meliputi kelembagaan atau institusi yang efisien dengan tata laksana yang jelas (transparan), diisi SDM yang profesional, mempunyai akuntabilitas tinggi kepada masyarakat serta menghasilkan pelayan publik yang prima (Tamin, 2004:25-26). Reformasi birokrasi diperlukan agar birokrasi sebagai bagian dari institusi penyelenggara pemerintahan selalu menempatkan kepentingan publik sebagai panglima. Bahwa birokrasi dan aparaturmya harus peduli terhadap kepentingan publik dan selalu menjadikan kepentingan publik sebagai kriteria utama dalam pengambilan keputusan (Dwiyanto, 2011: 317).

Menurut Kasim dalam Maulana Ali (2012:176), reformasi administrasi/birokrasi adalah upaya perubahan melalui pendekatan dari atas ke bawah dengan program reorganisasi, pelangsingan (downsizing), program penghematan biaya, dan program reengineering. Menurut Caiden dalam Maulana Ali (2012:175), "reformasi birokrasi adalah istilah yang dipakai untuk menunjuk berbagai macam kegiatan seperti kegiatan penyempurnaan organisasi, pemeriksaan administratif, ...pengobatan terhadap segala macam ketidakberesan organisasi, ...sarana untuk menciptakan pemerintahan yang lebih bersih, dan gaya diri seorang pembaru organisasi”. Reformasi administrasi/ birokrasi berarti juga sebagai penggunaan kekuasaan dan pengaruh untuk menerapkan ukuran-ukuran baru pada suatu sistem administrasi guna mengubah tujuan, struktur ataupun prosedur dengan maksud meningkatkannya untuk kepentingan pembangunan.

Reformasi birokrasi akan mendorong pelaksanaan good governance berjalan dengan baik, lebih transparan, akuntabel, dan inovatif. Perbaikan dan pembaruan birokrasi pemerintah daerah, harus diarahkan pada tiga kepentingan yaitu pertama memberikan pelayanan yang lebih baik kepada masyarakat. Kedua, mempertanggungjawabkan penerimaan maupun penggunaan sumber-sumber keuangan publik. Dan ketiga, meningkatkan efisiensi dan efektifitas internal instansi pemerintah, terutama menjadikan anggaran publik sebagai salah satu basis pengambilan keputusan (Prasojo dan Kurniawan, 2008; Fukuyama, 2015).

\section{Reformasi Birokrasi dan Kinerja Ekonomi Daerah}

Samonte dalam Mustafa (2013:136) mengartikan reformasi sebagai perubahan-perubahan atau inovasi-inovasi dengan penggunaan perencanaan dan adopsi untuk membuat sistem administrasi sebagai badan atau agen yang lebih efektif untuk perubahan sosial; sebagai instrumen yang baik untuk membawa persamaan politik, kemudian sosial, dan perubahan ekonomi.

Untuk menggairahkan kinerja sektor perekonomian, reformasi birokrasi adalah sebuah keniscayaan. Reformasi birokrasi diperlukan untuk menata ulang, mengubah, menyempurnakan dan memperbaiki birokrasi agar menjadi lebih bersih, cepat tanggap, kreatif, efisien, efektif dan produktif. Dengan demikian, pelaku ekonomi mendapatkan situasi yang lebih kondusif untuk menjalankan usaha tanpa terbebani urusan bertele-tele di luar urusan bisnis yang mereka lakukan (Gunarjo, 2011:57).

Pembangunan ekonomi merupakan salah satu jalan untuk mensejahterakan rakyat, dalam pembangunan ekonomi tersebut diperlukanlah reformasi birokrasi yang ramah terhadap semua lapisan unit usaha, mulai dari investor, pemilik perusahaan bahkan sampai pegawai. Dalam pembangunan ekonomi berkaitan erat dengan bergeraknya sektor ekonomi yang menciptakan lapangan kerja bagi seluruh masyarakat sehingga tujuan negara dalam memakmurkan rakyatnya tercapai. Peningkatan kualitas birokrasi akan meningkatkan pertumbuhan ekonomi. Jika ekonomi 
berkembang maka akan banyak lowongan kerja dan akan meningkatkan pendapatan masyarakat. Jadi dari segala aspek kualitas birokrasi akan memberikan dampak yang sangat signifikan kepada negara (Azizah, 2015).

Tujuan reformasi birokrasi terkait sektor ekonomi adalah terwujudnya birokrasi yang bersih. Bersih di sini berarti bebas dari praktek KKN, melalui pembenahan sistem pengelolaan anggaran, perbaikan kesejahteraan pegawai, peningkatan pengawasan, penegakan aturan-aturan hukum. Reformasi birokrasi juga ditujukan untuk mewujudkan birokarasi yang efisien. Efisiensi dilakukan melalui program penghematan bagi pembiayaan operasional birokrasi. Selain itu, reformasi diharapkan dapat mewujudkan birokrasi yang transparan. Transparansi di sini bermakna pembukaan ruang publik dan publik dapat mengakses secara luas penyelenggaraan urusan pemerintahan dan pelayanan umum. Namun yang terpenting adalah mewujudkan perubahan dari birokrasi yang primordialisme atau minta dilayani menjadi birokrasi yang melayani masyarakat (Gunarjo, 2011:57).

Basri (2002: 122-154) menganalogikan permasalahan ekonomi sebagai penyakit berat, bahwa penyelesaian ekonomi tidak bisa langsung teratasi. Ada tahapannya, untuk penyakit ekonomi, tahap pertama yang harus dilalui adalah rehabilitasi dan stabilisasi dengan tugas pokok penyediaan kebutuhan pokok dan pengendali inflasi, dan tahap kedua melalui pembenahan sistem insentif. Pemerintah disini lebih bertindak sebagai pembuat jaring-jaring pengaman dan sistem insentif, dan menerapkan pendekatan pembangunan yang semakin proaktif untuk lebih mengedepankan aspek kedaerahan (spatial). Reformasi dan restrukturisasi administrasi publik dibutuhkan dengan pengoptimalan peran pemerintah yang andal. Menurut beliau, jika reformasi administrasi publik tidak ditempatkan sebagai prioritas utama dan mendesak untuk ditangani, akan meningkatkan biaya transaksi (transaction cost) yang mengganggu pola keunggulan komparatif dan akhirnya konsumenlah (masyarakat) yang menanggung beban. Dalam menghadapi semakin berperannya sektor swasta, kualitas birokrasi harus betul-betul menjadi perhatian utama untuk menjaga citra birokrasi yang bersih dan berwibawa, penguatan fungsi dan peranan birokrasi yang sangat strategis dalam menyebarkan visi dan misi pembangunan. Bahwa tanpa reformasi dalam sektor administrasi publik yang cenderung membuat langkah reformasi ekonomi yang dilakukan pemerintah saat ini akan semakin kurang efektif dalam mendorong efisiensi karena birokrasi merupakan salah satu pelaku ekonomi yang juga menentukan jalannya mekanisme pasar.

Penelitian yang dilakukan Akhmaddian (2012) pada perizinan di Kota Bekasi menyimpulkan bahwa dengan dilaksanakan reformasi birokrasi, baik dengan penyederhanaan prosedur, penghematan waktu, dan langkah lainnya memberikan manfaat dalam proses pelayanan yang berorientasi kepuasan publik, dan secara tidak langsung masyarakat mendapatkan manfaat dengan mudahnya perizinan, pengusaha dapat membuka lapangan kerja karena proses penanaman modal berjalan dengan baik.

Aparat pemerintah daerah harus kreatif dalam mengembangkan setiap potensi yang mereka miliki sebagai usaha untuk meningkatkan PAD. Peningkatan PAD ini dapat mereka peroleh melalui pajak dan penarikan investasi ke daerah, yang akan memacu pertumbuhan ekonomi. Untuk menarik investasi ini, pemerintah daerah harus mampu mengembangkan birokrasi yang efisien, tidak korup, demokratis, dan ramah terhadap investasi. Kita membutuhkan wajah birokrasi yang baru, yang mampu bertindak sebagai kreator dan inovator dalam pembangunan daerah (Winarno, 2008:45). 
Suatu sistem birokrasi pemerintah daerah yang efisien, transparan, dan akuntabel hendaknya menjadi acuan kerja guna meningkatkan PAD sebagai modal utama untuk melakukan pembangunan ekonomi di daerahnya (Winarno, 2008:46). Hal ini dikarenakan masalah birokrasi pemerintahan selalu memiliki sisi negatif bagi perekonomian suatu daerah. Birokrasi pemerintahan yang berbelitbelit akan membuat kalangan investor berpikir dua kali untuk melakukan investasi di daerah bersangkutan. Jika investor menerapkan "wait and see” dalam melakukan investasi, maka dapat dipastikan pertumbuhan perekonomian negara akan terganggu (Priyono, 2014).

Terciptanya suatu pemerintah daerah yang akuntabel menjadi suatu harapan tersendiri bagi masyarakat, sehingga tercipta suatu sistem pertanggungjawaban pemerintah daerah sebagai entitas yang mengelola dan bertanggung jawab atas penggunaan kekayaan daerah. Dengan terciptanya pemerintah daerah yang akuntabel berarti semakin sedikit terjadinya permasalahan information asymmetry, sehingga semakin sedikit peluang terjadinya penyelewengan atau korupsi oleh pihak pemerintah daerah (agent). Disisi lain, pelaporan keuangan suatu daerah yang akuntabel maka aliran dana untuk pembangunan daerah tersebut sudah teralokasi dengan benar yang akan meningkatkan pertumbuhan ekonomi suatu daerah tersebut, dan sebaliknya (Mardiasmo, 2009 dalam Masdiantini dan Adi, 2016: 1155-1156).

\section{HASIL DAN PEMBAHASAN}

Reformasi Birokrasi (RB) adalah upaya sadar pemerintah daerah dalam menjawab tuntutan publik. Perubahan mekanisme birokrasi menjadi lebih cepat, mudah, murah, efektif, dan efisien menjadi ukuran tata kelola pemerintahan yang optimal. Keberhasilan melakukan RB tersebut pada akhirnya akan melahirkan penghargaan-penghargaan yang diterima oleh pemerintah daerah, dan cenderung digunakan sebagai paramater oleh dunia usaha untuk berinvestasi pada daerah tersebut. Menpan-RB, Yuddy Chrisnandi (2015) menegaskan bahwa harus ada terobosan dan debirokratisasi dalam pelayanan publik agar lebih cepat dan berkualitas jika pemerintah daerah ingin menggenjot investasi serta meningkatkan pertumbuhan ekonomi dan PAD.

Seperti dijelaskan sebelumnya, terlebih dahulu dilakukan analisis terhadap pengaruh 3 komponen reformasi birokrasi (Opini BPK, AKIP, dan Kepatuhan Pelayanan Publik) terhadap pendapatan asli daerah. Analisis statistik 3 komponen tersebut terhadap PAD dilakukan untuk menemukan pengaruh perbaikan RB tersebut terhadap besaran potensi PAD yang akan ditimbulkan. Kemudian dilanjutkan dengan analisis pengaruh pendapatan asli daerah tersebut terhadap pertumbuhan ekonomi daerah. Diharapkan ketiga komponen tersebut memberikan pengaruh positif terhadap PAD, dan selanjutnya secara langsung juga memberikan pengaruh positif terhadap kemajuan ekonomi daerah.

\section{Pengaruh Akuntabilitas Kinerja Pemerintah Daerah Terhadap PAD}

Terkait akuntabilitas kinerja, secara umum pemerintah daerah di Indonesia relatif masih memiliki tingkat akuntabilitas yang cukup rendah meskipun secara bertahap mulai menunjukkan perbaikan yang signifikan seiring percepatan penerapan reformasi birokrasi gelombang kedua sejak tahun 2010. Hal ini dapat dibuktikan dengan semakin membaiknya hasil penilaian akuntabilitas kinerja instansi pemerintah dari kementerian PAN dan RB hingga tahun 2014. 
Hasil pengolahan data terkait pengaruh akuntabilitas kinerja pemerintah daerah dalam peningkatan PAD secara lengkap dapat dilihat sebagai berikut:

Tabel 2.

HasilRegresiVariabel $\mathrm{X}_{1}$ terhadapVariabel Y

- reg pad1 akip

\begin{tabular}{|c|c|c|c|c|c|c|}
\hline Source & SS & df & MS & Number of obs & & \\
\hline $\begin{array}{r}\text { Model } \\
\text { Residual }\end{array}$ & $\begin{array}{l}1.8973 e+19 \\
2.7896 e+20\end{array}$ & $\begin{array}{r}1 \\
94\end{array}$ & $\begin{array}{l}1.8973 e+19 \\
2.9677 e+18\end{array}$ & $\begin{array}{l}\text { Prob > F } \\
\text { R-sared }\end{array}$ & $=$ & 0.0131 \\
\hline Total & $2.9793 e+20$ & 95 & $3.1361 \mathrm{e}+18$ & $\begin{array}{l}\text { Adj R-squared } \\
\text { Root MSE }\end{array}$ & & $\begin{array}{l}0.0537 \\
1.7 e+09\end{array}$ \\
\hline
\end{tabular}

\begin{tabular}{r|rcccrr}
\hline pad1 & Coef. & Std. Err. & $t$ & P $>|t|$ & [95\% Conf. Interva1] \\
\hline akip & $9.78 e+08$ & $3.87 e+08$ & 2.53 & 0.013 & $2.10 e+08$ & $1.75 e+09$ \\
_cons & $1.66 e+08$ & $3.26 e+08$ & 0.51 & 0.612 & $-4.81 e+08$ & $8.12 e+08$
\end{tabular}

Hasil regresi tersebut memperlihatkan bahwa jika akuntabilitas kinerja pemerintah daerah mengalami perbaikan (dari kategori buruk (D dan C) ke level kategori CC (cukup) atau meningkat ke B (baik)) maka akan memberikan pengaruh secara statistik signifikan (statistically significant) pada level kepercayaan 95\% terhadap peningkatan PAD. Dengan demikian, dapat disimpulkan bahwa semakin membaiknya nilai akuntabilitas kinerja pemerintah daerah akan memberikan dampak positif terhadap peningkatan jumlah PAD yang semakin besar. Hal ini semakin mempertegas bahwa pemerintahan yang akuntabel meningkatkan kepercayaan publik dan dunia usaha pada setiap program dan kegiatan yang dijalankan pemerintah daerah, oleh karenanya disebutkan bahwa transparansi dan akuntabilitas menjadi indikator penting profesionalisme birokrasi (Zuhro, 2007).

Contoh nyata ditunjukkan oleh Kabupaten Batang, yang mendorong tata kelola dan transparansi anggaran dengan memamerkan anggaran dan penggunaannya ke publik melalui "Festival Anggaran" setiap tahunnya. Dari kebijakan ini Pemerintah Kabupaten Batang dapat memicu peningkatan PAD hingga 300 persen di Tahun 2015-2016.

Dari ke-99 sampel yang digunakan dalam penelitian ini, sebagian besar pemerintah daerah yang menjadi pilot project reformasi birokrasi tersebut mampu mendapatkan penilaian AKIP pada kategori CC atau cukup yang merupakan target umum reformasi birokrasi. Disisi lain, beberapa pemerintah daerah (baik pemerintah provinsi, kabupaten, dan kota) mampu melewati target tersebut dan memperoleh predikat baik atau kategori B. 


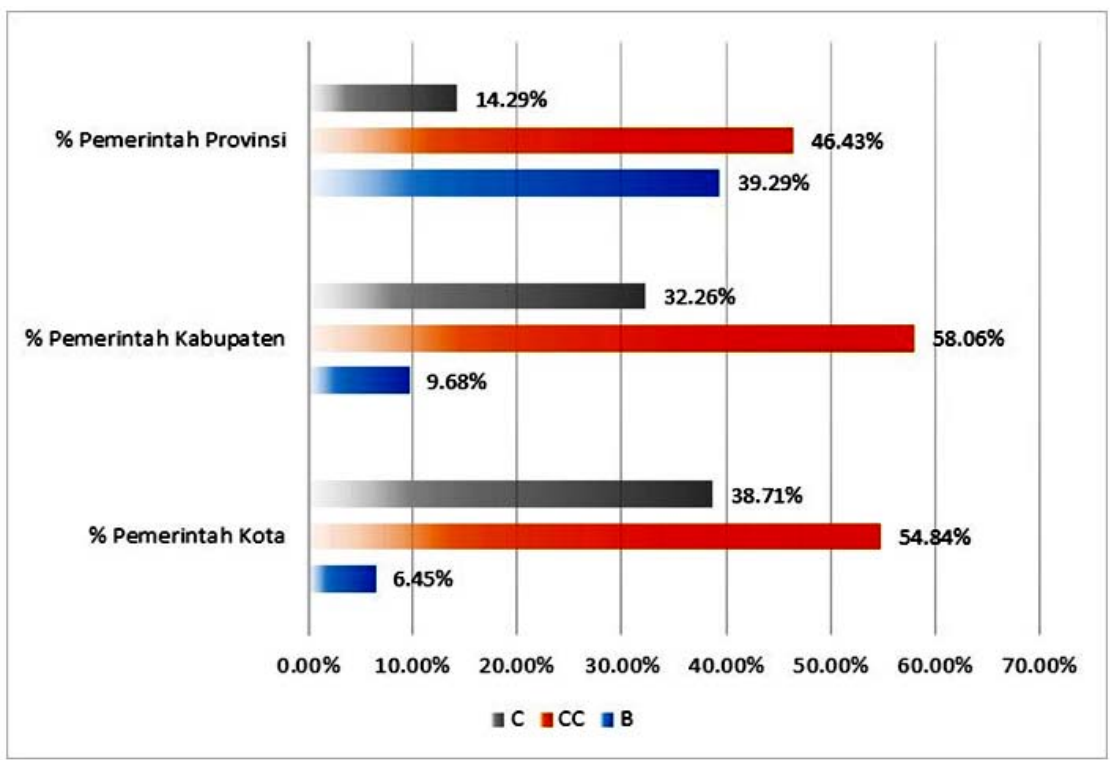

Gambar 3.

Persentase Hasil Penilaian AKIP pada 99 Pemerintah Daerah Tahun 2014

Chart di atas menunjukkan bahwa beberapa pemerintah daerah masih memerlukan pembenahan terhadap akuntabilitas kinerjanya. pada tingkat pemerintah provinsi yang masih berada pada kategori C sebanyak 4 pemda, pemerintah kabupaten sebanyak 10 pemda, dan pemerintah kota sebanyak 12 pemda.Akuntabilitas yang rendah tentu cenderung mendorong terjadinya korupsi, dan fakta layanan publik di Indonesia menunjukkan bahwa sektor pelayanan publik masih rawan korupsi dalam bentuk penyuapan, pemerasan, gratifikasi ataupun penyalahgunaan wewenang (KPK, 2015).

\section{Pengaruh Kinerja Pengelolaan Keuangan Pemerintah Daerah Terhadap PAD}

Adapun hasil penilaian Badan Pemeriksaan Keuangan terhadap Laporan Keuangan Pemerintah Daerah Tahun 2014 secara umum menunjukkan masih ditemukannya pemborosan, ketidakefisienan, dan ketidakefektifan penggunaan anggaran daerah, sehingga berpengaruh pada tingkat akuntabilitas laporan keuangan yang ada. Adapun hasil regresi terkait kinerja pengelolaan keuangan pemerintah daerah dengan acuan opini BPK terhadap PAD sebagai berikut:

Tabel 3.

Hasil Regresi Variabel $\mathrm{X}_{2}$ terhadap Variabel Y

- reg pad1 bpk

\begin{tabular}{r|crc} 
Source & SS & df & MS \\
\hline $\begin{array}{r}\text { Mode1 } \\
\text { Residua1 }\end{array}$ & $\begin{array}{r}3.3201 \mathrm{e}+16 \\
2.9827 \mathrm{e}+20\end{array}$ & $\mathbf{1}$ & $\mathbf{3 . 3 2 0 1 \mathrm { e } + 1 6}$ \\
\hline Total & $2.9831 \mathrm{e}+20$ & 96 & $3.1074 \mathrm{e}+18$
\end{tabular}

$$
\begin{array}{llr}
\text { Number of obs } & & 97 \\
\text { FC 1, 95) } & =0.01 \\
\text { Prob }>\text { F } & = & 0.9183 \\
\text { R-squared } & = & 0.0001 \\
\text { Adj R-squared } & = & -0.0104 \\
\text { Root MSE } & = & 1.8 \mathrm{e}+09
\end{array}
$$

\begin{tabular}{r|rcccrr}
\hline pad1 & Coef. & Std. Err. & t & P>|t I & [95\% Conf. Interva1] \\
\hline bpk & $3.88 e+07$ & $3.77 e+08$ & 0.10 & 0.918 & $-7.10 e+08$ & $7.87 e+08$ \\
_cons & $8.27 e+08$ & $3.04 e+08$ & 2.72 & 0.008 & $2.23 e+08$ & $1.43 e+09$ \\
\hline
\end{tabular}


Hasil tersebut di atas menunjukkan bahwa pencapaian opini WTP oleh pemerintah daerah relatif secara statistik tidak menunjukkan signifkasi yang kuat terhadap peningkatan PAD (tingkat kepercayaannya sangat kecil yakni dibawah 10\%). Namun demikian, tanda (sign) dari koefisien dari variabel BPK menunjukkan tanda positif sehingga relatif terdapat efek positif (meskipun tidak signifikan). Hasil ini tentu cukup mengejutkan sebab diasumsikan semakin membaiknya opini laporan keuangan pemerintah daerah maka akan berimbas pada peningkatan daya tarik daerah bagi aktivitas ekonomi dan pembangunan sehingga PAD cenderung meningkat. Namun demikian, sebagaimana penjelasan (Permenpan-RB No. 11/ 2011:9) disebutkan bahwa opini BPK tidak terkait dengan kinerja keseluruhan Kementerian/ Lembaga dan Pemerintah Daerah, sebab pemeriksaan keuangan bukanlah pemeriksaan (audit) kinerja. Penjelasan inilah yang dapat dijadikan acuan mengapa variabel BPK tidak signifikan mempengaruhi variabel PAD.

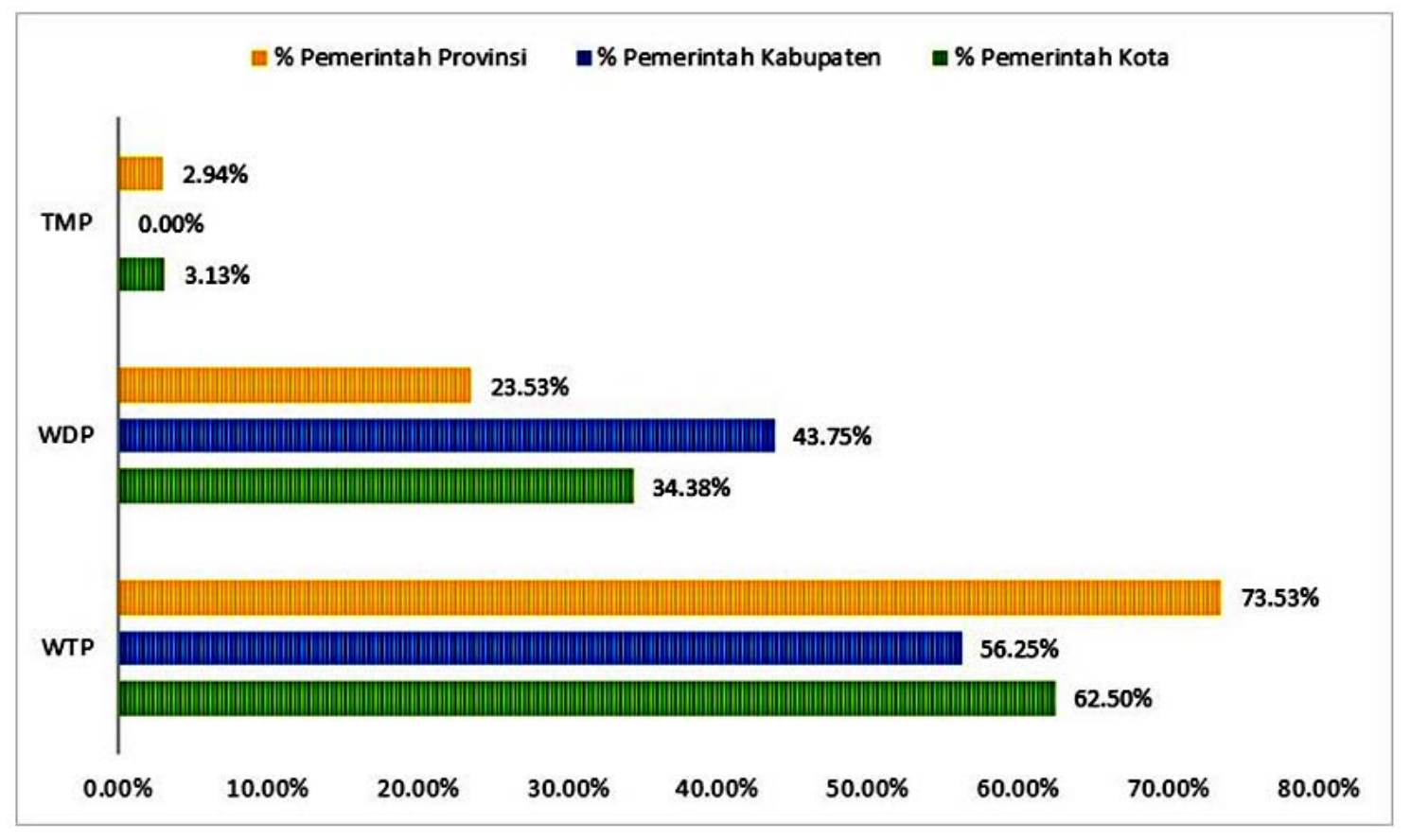

Gambar 4.

Persentase Pencapaian 99 Pemerintah Daerah Berdasarkan Opini BPKTahun 2014

Dari Gambar 4,baik pemerintah provinsi, pemerintah kabupaten, maupun pemerintah kota secara umum didominasi oleh pencapaian opini WTP (Wajar Tanpa Pengecualian) dari BPK yang merupakan opini tertinggi dan terbaik atas pengelolaan keuangan daerah.Pada level provinsi, Provinsi Banten (2013-2014) mengalami penurunan drastis dari Wajar Dengan Pengecualian (WDP) ke TMP (Tidak Memberikan Pendapat) selama kurun 2 tahun terakhir tersebut seiring tertangkapnya gubernur Banten akibat kasus korupsi. Sedangkan pada level kabupaten/ kota terdapat Pemerintah Daerah Manokwari yang masih memperoleh opini TMP(Tidak Memberikan Pendapat) yang merupakan penilaian terendah dari hasil audit BPK.

Kementerian PAN dan RB telah menetapkan target baru dalam perencanaan strategis terkait pencapaian tata kelola keuangan daerah yang lebih baik pada tahun 2019. Target ini diharapkan akan mendorong pemerintah daerah untuk melakukan reform terhadap pengelolaan keuangan daerah menjadi lebih bersih dan bebas dari unsur KKN. 
Tabel 4.

Target Pencapaian Opini Keuangan Daerah

\begin{tabular}{|l|c|c|}
\hline \multicolumn{1}{|c|}{ Keterangan } & Baseline 2014 & Target 2019 \\
\hline Rata-rata nasional WTP Pemerintah Provinsi & $52 \%$ & $85 \%$ \\
\hline Rata-rata nasional WTP Pemerintah Kabupaten & $30 \%$ & $60 \%$ \\
\hline Rata-rata nasional WTP Pemerintah Kota & $41 \%$ & $65 \%$ \\
\hline
\end{tabular}

\section{Pengaruh Kinerja Pelayanan Publik Pemerintah Daerah Terhadap PAD}

Pelayanan publik merupakan salah satu ukuran penting keberhasilan birokrasi dalam memberikan pelayanan yang memuaskan kepada publik. Pelayanan publik yang excellent melahirkan kepercayaan publik dan dapat mendorong iklim pemerintahan dan bisnis yang stabil. Berdasarkan pengolahan regresi keterkaitan antara kinerja pelayanan publik terhadap PAD dengan menggunakan software pengolah data STATA 11.2, diperoleh hasil sebagai berikut:

Tabel 4.

HasilRegresiVariabel $\mathrm{X}_{3}$ terhadapVariabel Y

\begin{tabular}{r|crc} 
- reg pad1 & \multicolumn{1}{l}{ or $\mathrm{r}$} \\
Source & SS & df & MS \\
\hline $\begin{array}{r}\text { Mode1 } \\
\text { Residua1 }\end{array}$ & $2.7891 \mathrm{e}+19$ & 1 & $2.7891 \mathrm{e}+19$ \\
& $2.5365 \mathrm{e}+20$ & 72 & $3.5230 \mathrm{e}+18$ \\
\hline Tota1 & $2.8154 \mathrm{e}+20$ & 73 & $3.8568 \mathrm{e}+18$
\end{tabular}

Number of obs $=\quad 74$

$F(1,72)=7.92$

Prob > F $=0.0063$

R-squared $\quad=0.0991$

Adj R-squared $=0.0866$

$\begin{array}{ll}\text { Root MSE } & =1.9 e+09\end{array}$

\begin{tabular}{r|rcccrr}
\hline pad1 & Coef. & Std. Err. & t & P>|t| & [95\% Conf. Interva1] \\
\hline ori & $1.23 e+09$ & $4.38 e+08$ & 2.81 & 0.006 & $3.59 e+08$ & $2.10 e+09$ \\
_cons & $4.05 e+08$ & $3.22 e+08$ & 1.26 & 0.212 & $-2.36 e+08$ & $1.05 e+09$ \\
\hline
\end{tabular}

Hasil olahan data tersebut menunjukkan hasil yang baik, dimana jika pemerintah daerah mampu memperbaiki pelayanan publiknya atau memiliki kepatuhan yang semakin tinggi(dibuktikan dengan pencapaian pelayanan publik dari zona merah (rendah) ke zona kuning (cukup) atau ke zona hijau (tinggi)) terhadap standar pelayanan publik, maka secara statistik signifikan akan meningkatkan jumlah PAD daerah pada tingkat kepercayaan 99\%. Kondisi ini mengindikasikan pentingnya pemerintah daerah membenahi pelayanan publik daerahnya seoptimal mungkin. Hasil ini juga menjadi daya dorong bagi pemerintah daerah secara umum untuk meningkatkan kepatuhan terhadap standar pelayanan publik yang telah ditetapkan dengan berupaya mencapai zona hijau untuk seluruh unit pelayanan publiknya. Pada akhirnya, peningkatan pencapaian zona hijau tersebut akan mendorong peningkatan PAD secara langsung dengan nilai yang berlipat ganda sebagaimana ditunjukkan pada hasil analisis statistik tersebut.Hal ini selaras dengan penelitian sebelumnya yang dilakukan oleh Evans dan Rauch (1999) yang membuktikan bahwa kualitas pemerintahan yang baik akan meningkatkan pertumbuhan ekonomi.

Pemerintah daerah yang berada pada zona hijau atau zona tertinggi kepatuhan terhadap standar pelayanan publik masih sangat sedikit/ kecil yaitu 2 pemda ditingkat kota, dan 3 pemda di tingkat provinsi. Sedangkan yang berada pada zona kuning atau zona cukup pada 
level kota sekitar 50\%, level provinsi 52.94\%, sedangkan pada level kabupaten cukup rendah yaitu 27.27\%. Adapun pemerintah daerah yang kinerja pelayanan publiknya masih buruk atau berada pada zona merah pada level kabupaten cukup tinggi yaitu 72.73\%, diikuti oleh pemerintah kota sebesar $43.33 \%$, dan ditingkat pemerintah provinsi sebesar $38.24 \%$.

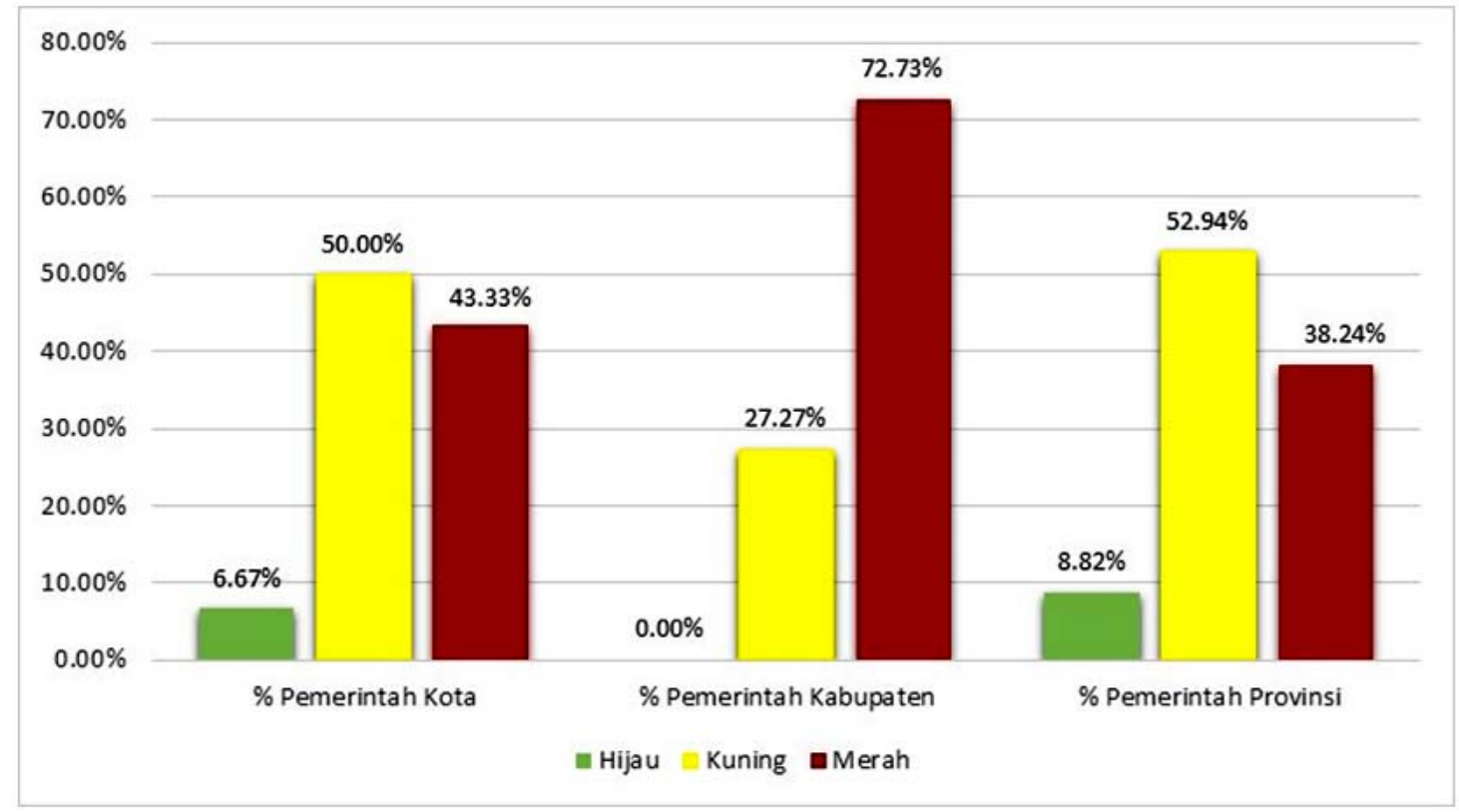

Gambar 5.

Persentase Hasil Penilaian Kinerja Pelayanan Publik Pada 99 Pemerintah Daerah Tahun 2014

Salah satu area perubahan dalam grand desain reformasi birokrasi adalah perbaikan pelayanan publik melalui optimalisasi penerapan standar pelayanan publik. Namun demikian, dari hasil penilaian ombudsman tersebut dapat dipastikan masih cukup banyaknya pemerintah daerah yang berada pada zona merah, yang menggambarkan tingkat kepatuhan yang relatif masih rendah bagi aparatur pemerintah dalam menjalankan standar pelayanan publik sehingga berdampak pada kurang berfungsinya birokrasi dalam melayani publik dengan baik.Pada tahun 2014, laporan/ pengaduan masyarakat atas dugaan maladministrasi dalam pelayanan publik ke ORI mencapai 6.677 laporandan meningkat di tahun 2015 menjadi 6.859 laporan bahkan di April 2016 sudah lebih dari 2000 laporan yang diprediksikan ORI akan terus meningkat ${ }^{1}$. Dari 6.859 laporan di tahun 2015, sebanyak 41.59\% atau 2.853 laporan mengeluhkan pelayanan publik di instansi pemerintah daerah. Laporan statistik Pengaduan Masyarakat Tahun 2015 oleh Ombusdman, menyebutkan laporan/pengaduan masyarakat karena dugaan maladministrasi paling banyak pada pengaduan karena penundaan yang berlarut, penyimpangan prosedur, dan tidak memberikan pelayanan kepada masyarakat (ORI, 2015:10).

Rendahnya kepatuhan terhadap standar pelayanan publik secara langsung mengakibatkan maladministrasi berupa ketidakpastian hukum, ketidakakuratan pelayanan dan praktek-praktek pungli pada penyelenggaraan pelayanan publik dari pusat sampai ke daerah. Pengabaian

\footnotetext{
1 http://ombudsman.go.id/index.php/berita/berita/siaran-pers-ombudsman/1631-kualitas-pelayanan-publikmasih-jauh-dari-harapan.htmldiunduh 2 Mei 2016
} 
terhadap standar pelayanan mengakibatkan kualitas pelayanan publik buruk dan juga akan mendorong terjadinya potensi perilaku mal-administrasi yang berujung pada inefisiensi birokrasi dan perilaku koruptif(Ombudsman, 2015).

\section{Pengaruh RB Terhadap PAD dan Pertumbuhan Ekonomi Daerah}

Berdasarkan hasil perhitungan secara statistik pada tiga komponen RB sebelumnya, diperoleh hasil bahwa ketiga komponen RB tersebut menunjukkan pengaruh positif (positif sign) terhadap peningkatan PAD, namun hanya dua komponen yang memberikan dampak signifikan yaitu Akuntabilitas Kinerja Pemerintah Daerah (Variabel AKIP) dan Kinerja Pelayanan Publik Pemerintah Daerah (Variabel ORI). Dengan demikian, relatif secara umum dapat disimpulkan bahwa pelaksanaan RB mampu memberikan pengaruh terhadap peningkatan PAD pemerintah daerah. Keberhasilan pemerintah daerah mencapai peringkat Akuntabilitas Kinerja Pemerintah Daerah dan Kinerja Pelayanan Publik Pemerintah Daerah yang semakin membaikkedepannya, akan semakin mempercepat peningkatan PAD.

Keberhasilan RB dalam wujud peningkatan PAD ini tentu akan memberikan dampak turunan kepada pertumbuhan ekonomi daerah. Berdasarkan hasil regresi dengan menggunakan software pengolah data STATA 11.2, diperoleh hasil sebagai berikut:

Tabel 5.

HasilRegresi

- reg pdrb pad

\begin{tabular}{r|crc} 
Source & SS & df & MS \\
\hline $\begin{array}{r}\text { Mode1 } \\
\text { Residual }\end{array}$ & .001419202 & 1 & .001419202 \\
\hline Total & .0316242687 & 96 & .000315028 \\
\hline & & 97 & .000326411
\end{tabular}

$\begin{array}{llr}\text { Number of obs } & = & 98 \\ \text { F } 1, \quad 96) & =4.51 \\ \text { Prob }>\text { F } & =0.0364 \\ \text { R-squared } & = & 0.0448 \\ \text { Adj R-s quared } & = & 0.0349 \\ \text { Root MSE } & = & .01775\end{array}$

\begin{tabular}{r|rccccr}
\hline pdrb & Coef. & std. Err. & $t$ & P>|t| & \multicolumn{2}{c}{ [95\% Conf. Interva1] } \\
\hline pad & .0107692 & .0050739 & 2.12 & 0.036 & .0006977 & .0208408 \\
_cons & .0576981 & .0020179 & 28.59 & 0.000 & .0536926 & .0617035 \\
\hline
\end{tabular}

Hasil run di atas menunjukkan bahwa optimalnya RB yang ditandai dengan peningkatan pertumbuhan Pendapatan Asli Daerah (PAD) secara statistik signifikan mempengaruhi peningkatan pertumbuhan ekonomi daerah sebesar 1,1\%. Nilai P-Value dari variabel PAD signifikan (á < 5\%) yang berarti tingkat signifikansinya 95\% atau cukuptinggi.

PAD merupakan komponen penting dalam APBD daerah sebab secara aggregat dipergunakan oleh pemerintah daerah dalam membiayai program dan kegiatan pembangunan yang telah direncanakan. Sehingga semakin tinggi PAD, maka secara langsung pemerintah daerah dapat mendorong peningkatan pada belanja sektor publik, yang berefek pada tumbuhnya ekonomi daerah. 
Tabel 6.

Rata-Rata PAD, APBD, dan Kontribusi PAD Terhadap APBD pada 99 Pemerintah Daerah

\begin{tabular}{|l|c|c|c|c|c|c|c|c|}
\hline \multirow{2}{*}{ Pemerintah Daerah } & \multicolumn{3}{|c|}{ PAD (dalam juta Rp) } & \multicolumn{3}{c|}{ APBD (dalam juta Rp) } & \multicolumn{2}{c|}{$\begin{array}{c}\text { Kontribusi PAD } \\
\text { dalam APBD }\end{array}$} \\
\cline { 2 - 10 } & 2013 & 2014 & Progres & 2013 & 2014 & Progres & 2013 & 2014 \\
\hline Rata-Rata Kota & 372,969 & 425,888 & $29.24 \%$ & $1,557,825$ & $1,693,258$ & $7.58 \%$ & $23.94 \%$ & $25.15 \%$ \\
\hline Rata-Rata Kabupaten & 196,591 & 196,601 & $12.38 \%$ & $1,180,659$ & $1,207,098$ & $5.83 \%$ & $16.65 \%$ & $16.29 \%$ \\
\hline Rata-Rata Provinsi & $2,447,730$ & $3,002,410$ & $14.37 \%$ & $16,586,686$ & $18,206,637$ & $8.13 \%$ & $14.76 \%$ & $16.49 \%$ \\
\hline
\end{tabular}

Berdasarkan tabel di atas terlihat jelas bahwa PAD pemerintah daerah secara umum tumbuh cukup tinggi (rata-rata 18.7\%) dan kontribusinya dalam APBD relatif juga mengalami peningkatan. Kondisi ini menunjukkan bahwa pemerintah daerah telah secara serius mengupayakan penguatan fiskal daerahnya dalam neraca APBD. Dengan demikian, PAD juga dapat dinilai sebagai usaha otonom atau kemampuan pemerintah daerah dalam memperoleh pemasukan dengan mengandalkan kapabilitas birokrasinya. Oleh karenanya, upaya meningkatkan kapabilitas birokrasi dalam skema reformasi birokrasi terus dilaksanakan dan didorong oleh pemerintah daerah (termasuk pemerintah pusat) melalui upaya-upaya memperlancar bottle-neck yang selama ini dihadapi masyarakat, serta perbaikan terhadap kualitas pelayanan publiknya.Suatu sistem birokrasi pemerintah daerah yang efisien, transparan, dan akuntabel hendaknya menjadi acuan kerja guna meningkatkan PAD sebagai modal utama untuk melakukan pembangunan ekonomi di daerahnya (Winarno, 2008:46).

\section{E. PENUTUP}

\section{Kesimpulan}

Pemerintah daerah telah secara serius mengupayakan pelaksanaan RB di daerahnya melalui pembenahan pengelolaan birokrasinya secara optimal agar dapat memberikan pelayanan yang terbaik kepada publik serta menciptakan sosok birokrasi yang terpercaya dan akuntabel. Keseluruhan upaya tersebut diharapkan bermuara pada peningkatan kemakmuran daerah. Hasil penelitian ini memberikan dukungan bahwa RB secara umum mempengaruhi kemajuan ekonomi daerah secara positif. Semakin berhasil upaya RB yang dilakukan oleh pemerintah daerah akan mendorong pembangunan dan kesejahteraan publik yang lebih tinggi pula. Hal ini ditandai dengan peningkatan PAD untuk menjalankan program dan kegiatan pemerintah daerah yang selanjutnya akan berimbas pada progres atau peningkatan aktivitas ekonomi daerah.

\section{Rekomendasi}

Berdasarkan hasil analisis yang dilakukan, beberapa solusi alternatif untuk mengoptimalkan reformasi birokasi dalam mendorong kemajuan ekonomi daerah sebagai berikut:

1. Temuan penelitian ini secara umum menjelaskan bahwa upaya RB yang dilakukan secara serius akan mempengaruhi kemajuan ekonomi daerah. Oleh karena itu perlu dilakukan upaya meningkatkan pemahaman pemerintah daerah untuk membenahi birokrasinya secara optimal, sebab birokrasi yang dikelola dengan baik akan mendorong terciptanya iklim pemerintahan dan iklim usaha yang nyaman. Peningkatan pemahaman pemerintah daerah ini secara applicable dapat ditempuh melalui peningkatan kapasitas dan kompetensi aparatur pemerintah daerah. 
2. RB juga cenderung berhasil jika pemimpinnya cakap dalam memimpin reformasi atau pemimpin reformis. Sehingga, peran pemimpin daerah bukan saja penting, melainkan menentukan keberhasilan RB, sebab pemimpin merupakan trigger yang akan mempercepat terjadinya perubahan dalam birokrasi. Pemimpin reformis akan mendorong perubahan pola pikir dan culture-set birokrasi menjadi lebih disiplin, berorentasi pada pelayanan publik yang prima dan berkualitas, responsif, dan akuntabel yang pada akhirnya akan meningkatkan kinerja pembangunan daerah, dan pencapaian kesejahteraan publik.

3. Hasil analisis juga merekomendasikan untuk mendorong pencapaian yang lebih tinggi terhadap laporan Akuntabilitas Kinerja Instansi Pemerintah Daerah serta pembenahan pelayanan publik yang lebih baik melalui upaya-upaya penyederhanaan proses kerja, restrukturisasi, serta inovasi atau terobosan yang mempermudah publik dan dunia usaha.

4. Penelitian ini masih terbatas pada analisis kuantitatif-dokumentatif untuk periode yang relatif pendek, sehingga memerlukan penelitian lanjutan yang melihat secara time series serta juga melihat aspek kualitatif lainnya. Selainitu, faktor atau dimensi evaluasi pelaksanaan RB lainnya perlu dimasukkan untuk memetakan keberhasilan RB seutuhnya.

\section{DAFTAR PUSTAKA}

Akhmaddian, Suwari. (2012, September 3). Pengaruh Reformasi Birokrasi terhadap Perizinan Penanaman Modal di Daerah (Studi Kasus di Pemerintahan Kota Bekasi).Retrieved August 15, 2016, Dinamika Hukum:http://dinamikahukum.fh.unsoed.ac.id/index.php/ JDH/article/view/120/76

Azizah, N. P. (2015, Maret 6). Peran Reformasi Birokrasi dalam Pertumbuhan Ekonomi. April 15, 2016, Inspirasi Bangsa: http://inspirasibangsa.com/peran-reformasi-birokrasidalam-pertumbuhan-ekonomi/

Badan Pemeriksaan Keuangan. (2015). Ikhtisar Hasil Pemeriksaan Semester I Tahun 2015. Jakarta: Badan Pemeriksaan Keuangan.

Basri, Faisal H. (2002). Perekonomian Indonesia: Tantangan dan Harapan bagi Kebangkitan Indonesia. Jakarta: Erlangga.

Chrisnandi, Y. (2015, Desember 28). Reformasi Birokrasi Membidik Mental Aparatur dan Berbasis Kompetensi.April 15, 2016, Kementerian PAN-RB: http://www.menpan.go.id/ berita-terkini/4215-reformasi-birokrasi-membidik-mental-aparatur-dan-berbasiskompetensi/

Dwiyanto, A. (2011). Mengembalikan Kepercayaan Publik Melalui Reformasi Birokrasi. Yogyakarta: Gadjah Mada University Press.

Evans, Peter and Rauch, James E. (1999). Bureaucracy and Growth: ACross-National Analysis of the Effects of "Weberian" State Structures on Economic Growth. American Sociological Review, 64 (5), 748-765.

Fukuyama, F. (2015). Why is Democracy Performing so Poorly?. Journal of Democracy, 26(1), h. 11-20.

Gunarjo, N. (2011). Reformasi Birokrasi, Syarat Mutlak Pembangunan Ekonomi. Jurnal Dialog Kebijakan Publik, 3(September), h. 45-62.

Haniah Hanafie, Z. A. Achmady, Bambang Supriyono, dan Hermawan. (2015). Bureaucratic Reform in South Tangerang City. International Journal of Applied Sociology, 5(1), 41-50. 
Kementerian PAN dan RB. (2015). Laporan Hasil Penilaian Akuntantabilitas Kinerja Instansi Pemerintah Tahun 2015. Jakarta: Kementerian PAN dan RB.

Komisi Pemberantasan Korupsi (KPK). (2015). Laporan Tahunan 2014. Jakarta: KPK

KPPOD. (2012, Agustus 28). Mengintip Pelaksanaan Reformasi Perijinan. April 15, 2016, Komite Pemantauan Pelaksanaan Otonomi Daerah:http://www.kppod.org/index.php/ en/berita/berita-media/172-mengintip-pelaksanaan-reformasi-perijinan/

Kristiadi, J.B. (1995). Masalah Sekitar Peningkatan Pendapatan Asli Daerah. Jurnal Prisma, 4, 114

Kristiansen, S, dan Santoso, P. (2006). Surviving Decentralisation? Impacts of Regional Autonomy On Health Service Provision In Indonesia. Journal of Health Policy, 77(3), h.247-259.

Libman, A. (2009). Democracy, Size of Bureaucracy, and Economic Growth: Evidence From Russian Regions. Empirical Economics, 43(3), 1321-1352

Lovett, K. (2011, Maret 20). Institutional Design and Economic Growth: The Relationship between Bureaucracy and Economic Performance in a Global Economy. Retrieved April 15, 2016, from Carleton College: http://people.carleton.edu/ amontero/ Kelly\%20Lovett.pdf/

Marfiana dan Kurniasih. (2013). Pengaruh Karakteristik Pemerintah Daerah dan Hasil Pemeriksaan Audit BPK Terhadap Kinerja Keuangan Pemerintah Daerah Kabupaten/ Kota. JP Journal \& Proceeding FEB UNSOED, 3(1).

Masdiantini, P.R dan Adi Erawati, N.M. (2016). Pengaruh Ukuran Pemerintah Daerah, Kemakmuran, Intergovernmental Revenue, Temuan dan Opini Audit BPK Pada Kinerja Keuangan. E-Jurnal Akuntansi Universitas Udayana,14 (2), 1150-1182.

Maulana Ali, Eko. (2012). Kepemimpinan Transformasional dalam Birokrasi Pemerintahan. Jakarta: Multicerdas Publishing

Media Praja. (2015). Kalau Memang Bisa Dipercepat, Kenapa Harus Dipersulit?. Majalah Kementerian Dalam Negeri. Januari (2015), 12-13.

Mustafa, Delly. (2013). Birokrasi Pemerintahan. Bandung: ALFABETA

Nugroho, R. (2013). Reformasi Birokrasi, Sebuah Keharusan. In Kementerian PAN-RB, Pemimpin dan Reformasi Birokrasi : Catatan Inspiratif dan Alat Ukur Kepemimpinan Dalam Implementasi Reformasi Birokrasi (pp. 55-63). Jakarta: Kementerian PAN-RB dan Deutsche Gesellschaft fuer Internationale Zusammenarbeit (GIZ) GmbH Jerman.

Ombudsman Republik Indonesia, (2015). Ringkasan Hasil Penelitian Kepatuhan Pemerintah Pusat dan Pemerintah Daerah Terhadap Standar Pelayanan Publik Sesuai UU No. 25 Tahun 2009 Tentang Pelayanan Publik. Jakarta: Ombudsman Republik Indonesia

Prasojo, Eko and Kurniawan, Teguh. (2008). Reformasi Birokrasi dan Good Governance : Kasus Best Practices dari Sejumlah Daerah di Indonesia. Banjarmasin: The 5th International Symposium of Jurnal Antropologi Indonesia

Priyono, T. (2014, November 17). Reformasi Sistem Birokrasi di Era Jokowi. August 17, 2016, Detiknews: http://news.detik.com/kolom/2750103/reformasi-sistem-birokrasi-di-erajokowi 
Rauch, James E. (1995). Bureaucracy, Infrastructure, and Economic Growth: Evidence from U.S. Cities During the Progressive Era. The American Economic Review, 85(4), 968979.

Tamin, Feisal. (2004). Reformasi Birokrasi: Analisis Pendayagunaan Aparatur Negara. Jakarta: Blantika.

The World Bank. (2015, Januari 15). Worldwide Governance Indicators (WGI) 1996-2014. Retrieved April 15, 2016, from World Bank: http://info.worldbank.org/governance/ wgi/index.aspx\#countryReports/

Turner, Mark. (2013). Why Is It So Difficult to Reform Some Asian Bureaucracies? Building Theory From Cambodian Evidence. Public Administration and Development Journal, 33(4), 275-285.

Winarno, B. (2008). Globalisasi:Peluang atau Ancaman Bagi Indonesia. Jakarta: Penerbit Erlangga.

Zuhro, R. S. (2007, Februari 21). Birokrasi Sebagai Masalah Ekonomi Indonesia. Harian Bisnis Indonesia, h. 15. 